7 (2016)

D0I: $10.18276 /$ rk.2016.7-05

Adam Regiewicz

Akademia im. Jana Długosza w Częstochowie

\title{
Komparatystyka i czytanie dawności. Mediewalizm jako zjawisko translacyjne
}

Jednym z kierunków działania komparatystycznego jest

poszukiwanie relacji z tradycją i dziedzictwem, które warunkują współczesną tożsamość oraz integralność obecnej podmiotowości tak dziś zagrożonej przez „zwiotczałe mięśnie pamięci”. Podejmowany w tym zakresie wysiłek komparatystyki skupia się na odkrywaniu potencjału dziedzictwa, bowiem „bez dziedzictwa nie ma dziedziczenia”

(Steiner, 2009a: II),

a „bez poznania początku nie może być też poznania kontynuacji” (Husserl, 2008: 47). Wobec powyższego można stwierdzić, że teraźniejszość i przeszłość wzajemnie się warunkują: z jednej strony dzisiejsze odczytania przeszłości (czy dawności1) domagają się potwierdzenia w utekstowionych śladach przeszłości, z drugiej zaś trzeba mieć świadomość, co dzieje się z tymi śladami w czasie kolejnych odczytań - nabierają one cech czasów, w których są rekonstruowane czy interpretowane.

Takim właśnie wyobrażeniem dawności, które na podstawie śladu tejże przeszłości nabiera konkretnego kształtu w kulturze, jest mediewalizm² ${ }^{2}$ Leslie

\footnotetext{
1 Dawność definiowana jest przez niektórych badaczy jako przywoływanie jakiejkolwiek przeszłości, wobec której konstytuowany jest dystans czasowy. W niniejszych rozważaniach należałoby jednak rozdzielić tak rozumianą dawność od ukształtowanej w pewnych granicach czasowych i kulturowych przeszłości (Kaczmarek, 1992; Stoff, 1997; Dawność kulturowa, 1993).

2 Odpowiednikiem stosowanego w literaturze anglojęzycznej pojęcia medievalism, które w The Collins English Dictionary zostało zdefiniowane jako „a. wierzenia, życie lub styl średniowiecza bądź poświęcenie temu; b. przekonanie, zwyczaj, element stylu kopiowany lub taki, który przetrwał ze średniowiecza”, jest polskie pojęcie średniowieczność, które będzie pojawiało się w niniejszym tekście synonimicznie. Podaję za www.wordreference.com [dostęp: 13.12.2010].
} 
Workman - inicjator badań nad średniowiecznością - definiuje to pojęcie jako zjawisko konstruowania kształtu średniowiecza pod wpływem wyobrażeń odbiorcy - jego czytelniczych i kulturowych doświadczeń ${ }^{3}$. Co jednak bardziej istotne, mediewalizm nie jest zjawiskiem zamkniętym, które można opisywać poprzez zespół pewnych konstytutywnych cech czy właściwości charakterystycznych dla tego wyobrażenia kulturowego, ale raczej jawi się ,jako dyskurs, stosowany do kształtowania, kontestowania i komentowania innych czasów” (Simmons, 1998: 44). Postrzegając to zjawisko w nieco szerszej perspektywie, można by powiedzieć, że nadanie dawności nigdy nie jest możliwością jej odtworzenia, ale ponownego konstruowania, co w odniesieniu do omawianej tu średniowieczności zauważa Elizabeth Emery, pisząc, iż: „mediewalizm (...) nie jest tylko procesem odtwórczym, ale także twórczym i to w dwojakim sensie: budowania odwołań do wieków średnich oraz konstruowania samego średniowiecza” (Michalski, 2011: 86). Tym samym dawność jawi się jako zjawisko nieuchwytne, dynamiczne, konstytuowane w pewnym dyskursie, który odwzorowuje wartościujący ogląd świata, a zatem ktoś, kto bada sposoby uobecniania się znaków kultury dawnej (tu średniowiecznej), oscyluje między wyobrażeniem, światopoglądem, mentalnością czy nawet wiedzą odbiorcy a kulturą symboliczną danej społeczności (Regiewicz, 2014: 18-47).

Wobec tak rozumianego przedmiotu badań, najlepszym narzędziem do opisu relacji pomiędzy dawnością a jej śladami odbitymi w teraźniejszości wydaje się właśnie komparatystyka ze względu na jej transdyscyplinowy charakter, czy jak powie David Ferris, bycie dyscypliną ponad dyscypliną (Ferris, 2010: 246) ${ }^{4}$. Korzystając w badaniu dawności z narzędzi z zakresu różnych dziedzin i dyscyplin naukowych: od medycyny po politologię, które pozwalają na odkrywanie nowych powiązań między zewnętrznymi elementami, komparatystyka staje się jednocześnie manifestacją zakorzeniania w świecie, o czym przypomina Siegfried J. Schmidt, pisząc, iż zarówno badana praktyka kulturowa, jak i sam badacz są zanurzeni w „porządki symboliczne, dyskursy, systemy wartości, habitus i schematy [wyrażane] przez ich język" (Schmidt, 2010: 154). To holistyczne spojrzenie na rzeczywistość kulturową, przekraczające tym samym typowy dla dawnego rozumienia porządek binarny,

3 Stanowisko Leslie Workmana zostało zaprezentowane w pracach badawczych opublikowanych w zbiorze Medievalism in the Modern World. Essays in Honour of Leslie Workman.

4 Szeroko rozumiany paradygmat badań porównawczych - traktowanych jako wiedza lub styl „Czytania” zjawisk kulturowych, zorientowany na wzajemne oddziaływania, realne związki, pokrewieństwa i typologiczne odpowiedniości zjawisk literackich i pozaliterackich - skupia kulturowo zorientowaną wiedzę literaturoznawczą (poetyka kultury), sytuując ją w historycznym polu kultury i antropologicznej wiedzy o dyskursach trandyscyplinowych (Regiewicz, Utracka, 2011: 269). 
wpisany w tradycję dyscypliny (co wynika z samej nazwy - comparare), pozwala na inne niż dotychczas badanie relacji dawność-teraźniejszość.

Warto w tym miejscu zasygnalizować, że współczesna refleksja nad dawnością przyjmuje zasadniczo dwie postawy: pierwsza to próba zrekonstruowania historycznej rzeczywistości kulturowej ze wszystkimi jej kontekstami (stąd szczegółowe badania historyczne, zwrot ku archeologii, kult oryginału, o który coraz trudniej). Kryje się za nią pokusa ujmowania przeszłości jako pewnego i nienaruszonego czasu, do którego można wrócić, by go zrozumieć, obszaru zamkniętego, rozumianego także jako oddzielna jednostka kulturowa, stanowiąca świetną płaszczyznę porównań z czasami późniejszymi czy teraźniejszością. Druga postawa, wynikająca z rozwijających się wciąż badań postsekularnych, to próba czytania zjawisk dawnych nowym językiem metodologii po to, by - mówiąc za Derridą - odkryć to, co zakryte, co zaszyte w fałdach, pomiędzy słowami. Do analizy zjawisk kulturowo już nieobecnych wprowadza się zatem język, narzędzia interpretacyjne wywiedzione z nowych dyskursów naukowych, by odkrywać nowe znaczenia dawności. Ta postawa także rozdziela obie badane jednostki: dawność od współczesności.

Wobec powyższego chodziłoby zatem o wypracowanie trzeciej drogi - tertium comparationis, która, zderzając dawność i współczesność, „bada sieć relacji, nie widząc i nie chcąc widzieć "początków» i «końców»" (Kadłubek, 2010: 180). Taka komparatystyka niczego nie porównuje, ale troskliwie przygląda się splotom. Wobec przyjętych założeń komparatystyka po pierwsze, respektowałaby integralność, oddzielność dawności i współczesności, wszak przyjęcie optyki relatywizmu kulturowego rodzi przekonanie o niemożności „porównywania, prawomocnego opisywania i wyjaśniania jakichkolwiek kultur". Po drugie, postrzegałaby obie badane rzeczywistości jako dynamiczne jednostki kulturowe, podlegające nieustającej przemianie, co w odniesieniu do badań kulturowych postulował Charles Bernheimer w swoim raporcie (Bernheimer, 2010: 129). Wspomina o tym także Wojciech Kalaga, pisząc, iż tekst kulturowy (przeszłość jest takim samym tekstem jak wszystkie inne teksty kulturowe):

nie jest ani statycznym i niezmiennym konglomeratem znaczeń, ani tajemnicą do odszyfrowania, ani świątynią z ukrytym w niej Graalem - znaczeniem do odnalezienia; jest dynamicznym procesem; nieustannie zmieniającą się i pozostającą nieustannie w ruchu kondensacją znaczących relacji, holograficzną mgławicą w przestrzeni semiotycznej.

(Kalaga, 1998: 31) 
Po trzecie zaś, taka komparatystyka rekonstruowałaby dawność na wzór narracji, konceptualizującej się w momencie opowiadania na bazie wypracowanego w danym momencie systemu wspólnych przekonań, wartości, sądów (można przywołać tu także kognitywistyczne pojęcie amalgamatu kulturowego), które stają się punktem wyjścia dla wzajemnego porozumienia między przeszłością a współczesnością.

Ten ostatni postulat zwraca uwagę na retoryczny i interpretacyjny trop w refleksji nad komparatystyką, która ma służyć jako narzędzie do badania relacji dawności i współczesności. Ponieważ przeszłość jawi się jako konstrukcja fantazmatyczna, podlega ona procesom interpretacyjnym, o czym przypomina Andrzej Szahaj, pisząc: „Kultura epoki, w jakiej został wytworzony jakiś tekst kulturowy, wymaga takiej samej interpretacyjnej rekonstrukcji, jak ów sam tekst. Rekonstrukcji tych zaś może być wiele" (Szahaj, 1997: 15). Pytając zatem o dawność dziś, dokonuje się jej uobecnienia na podstawie interpretacji śladów przeszłości, czy idąc za rozwiązaniami retorycznymi, posługując się teorią przeniesienia: metaforą, synekdochą, metonimią, ironią 5 . W tym kontekście ciekawą propozycją wydaje się możliwość odniesienia badań nad dawnością (tu: mediewalizmem) do teorii translacji, jako praktyki przenoszenia języka, tekstu, znaczeń. „Trans-lacja jako przeniesienie, transport i relokacja” staje się w obecnej teorii przekładu jedną z ważniejszych praktyk badawczych, dzięki której to, co przeniesione (historyczne, dawne, mityczne), nie tylko może na nowo się rozwinąć, ale przede wszystkim stać się kluczem do zrozumienia teraźniejszości (Tymoczko, 2009: 430-431).

Praktykę przekładu można opisać na przykładzie zderzenia media aetas oraz new media, i nie chodzi tu tylko o postmodernistyczną grę słów ani też o budowanie porównania opartego na rozbieżności cywilizacyjnej obu jednostek kulturowych, którą każdy jest w stanie określić w kilku punktach, zazwyczaj sprowadzając je do różnic w rozwoju technologicznym i spoglądania z nieskrywaną wyższością na czasy dawne. Chodzi tu raczej, by zaproponowanemu zderzeniu towarzyszyła myśl zarysowana na początku XX wieku przez Nikołaja Bierdiajewa, a później kontynuowana przez Umberto Eco na temat przeżywania współcześnie „nowego średniowiecza”.

\footnotetext{
5 Teorię tropów wykorzystywanych w narratywistycznej koncepcji historii, dającej możliwość interpretacyjnego czytania wydarzeń dawnych Hayden White wyłożył w 1973 r. (White: 31-38)

6 Koncepcja ta oparta jest na przekonaniu o analogii, jaką można dostrzec pomiędzy tendencjami unifikacyjnymi w kulturze współczesnej - dokonującą się obecnie globalizacją, rozumianą jako proces rozpowszechniania wielu (niekoniecznie spójnych) wzorów, zachowań, norm i wartości w skali uniwersum, tworzącą wzajemną sieć powiązań obejmującą wszystkie płaszczyzny życia: egzystencjalne i społeczne, a wyrażającą się poprzez mechanizmy ekonomizacji i technicyzacji, a średniowiecznym uniwersalizmem (Bierdiajew, 2003; Eco, 1998: 74-101).
} 
Podążając za nią, dalsze rozważania poświęcone będą właśnie technologii jako płaszczyźnie zestawienia średniowiecza i współczesności, wychodząc od wypowiedzi Umberto Eco, który w swoim eseju The Return of the Middle Ages stawia ciekawą tezę, że mentalnie wciąż żyjemy pod wpływem średniowiecznej technologii. Pisze on:

wszystkie problemy zachodniego świata wyłoniły się właśnie w średniowieczu: języki nowożytne, miasta kupieckie, ekonomia kapitalistyczna (ze swymi bankami, czekami, stopami procentowymi) są wynalazkiem średniowiecznym, w tym okresie powstaje nowożytna armia, współczesne pojęcie państwa narodowego, jak również idea ponadnarodowej federacji [...], tarcia pomiędzy bogatymi a biednymi, koncepcja herezji i skrzywienia ideologicznego, a nawet nasze współczesne rozumienie miłości jako destrukcyjnego «nieszczęsnego szczęścia». Można dodać jeszcze konflikt pomiędzy państwem i Kościołem, związki zawodowe (choć w wersji korporacyjnej), czy przekształcenie rynku pracy przez technikę.

(Lewicki, 2010: 79-80)

Eco widzi technologię jako każdy rodzaj konstrukcji (także społecznych, ideologicznych), która ma na celu zabezpieczanie człowieka przed zagrożeniem i służy mu osiąganiu szczęścia. Technika maskuje poczucie niepewności jutra, strach przed codziennością, poczucie nietrwałości i niestabilności świata oraz sytuacji egzystencjalnej. Pomijając inne analogie, począwszy od poziomu wizualizacji doświadczenia rzeczywistości (katedra-fasada medialna, biblia pauperum-komiks), przez estetykę (otwartość na nadbudowywanie znaczeń, rozmywanie się granic w relacjach sztuka-technika), a skończywszy na konstrukcji społeczeństwa - sieciowego i średniowiecznego (anonimowość, budowanie komunikacji symbolicznej, mediewalizacja miasta), można założyć, że współczesne podejście do technologii jest wyrazem nowego średniowiecza, co postaram się ukazać na przykładzie katedry i jej konstrukcji architektonicznej.

Aby jednak nie wpaść w pułapkę „gramatyki podobieństw”, próba odczytania zestawienia media aetas oraz nowych mediów dokona się przy pomocy wspomnianej już teorii przekładu, który „umożliwia tekstowi dalsze życie w innym kontekście, zaś tekst przekładu staje się oryginałem poprzez sam fakt kontynuacji istnienia w tym nowym kontekście" (Bassnett, 2010: 497). W taki sposób należałoby spoglądać dziś na nowe media jako rodzaj remediacji średniowiecznych sposobów komunikowania i oswajania rzeczywistości. Nie do utrzymania wydaje się bowiem pokutująca jeszcze w niektórych środowiskach (szczególnie tych kultywujących ujęcie historyczne) dychotomia między dawnością a teraźniejszością, odczytywana w analogiczny sposób jako rozziew pomiędzy oryginałem a przekładem, źródłem a kopią. Nowoczesna teoria przekładu, wywodząca się z myślenia poststruktural- 
nego, postrzega proces translacji jako rodzaj manipulacji tekstem. Można nieco inaczej, mniej deprecjonująco, określić tę strategię jako przepisywanie, czy pisanie „na nowo”, które konstytuują obecność tekstu pierwotnego (dawności) w nowej ontologii ${ }^{7}$. Tłumaczenie rozumiane jako „twórcze pisanie” umożliwia pojednanie między tekstami: oryginalnym a przełożonym, staje się „odegraniem wydarzenia wspólnoty języków, obietnicą ich pogodzenia, zjednoczenia” (Bukowski, Heydel, 2009: 34; Derrida, 2009: 373-383). W proponowanym ujęciu badania dawności w centrum znajduje się nie tyle rekonstrukcja, ile właśnie remediacja, w której oryginał i przekład (przeszłość i współczesność) pozostają w relacji dialektycznej. Mediewalizm będzie zatem sięgać po zjawiska nowych mediów, przyglądać się im i próbować dostrzec zaszczepione z dawnej tradycji systemy kulturowe, wyobrażenia wywiedzione ze średniowiecza, sposoby budowania, wyrażania siebie i komunikowania się. Nie ulega bowiem wątpliwości, że nowe media jako przejaw remediacji są zjawiskiem hybrydycznym, co w języku teorii postkolonialnej wyrażałoby się w stwierdzeniu, że zawiera ono zarówno ontologię tubylczą (ową dawność średniowieczna), jak i kolonizatora (nowoczesną technologię).

Zarysowane tu napięcie można odnieść do jeszcze dwóch propozycji interpretacyjnych przekładu: kanibalizmu i polityczności. Pierwsza związana jest z ujęciem translacji jako świadomego aktu agresji dokonywanego na tekście oryginalnym. W krytyce feministycznej, o czym wspomina Hélène Cixous, taka postawa jest jednoznacznie interpretowana jako przejaw męskiej dominacji - „tłumacz najeżdża, pojmuje i bierze w niewolę" (Steiner 2009b: 330). W tym kontekście można też, za brazylijską szkołą przekładu, rozpatrywać translację jako zjawisko wampiryczne czy kanibalistyczne, zgodnie z którym tłumacz wysysa krew z tekstu źródłowego, by dać siłę tekstowi docelowemu. W ten sam sposób należałoby spojrzeć na działanie nowych mediów, które zasysają technologiczne idee z kultury średniowiecza, nadając im współczesne, dopasowane do obecnych możliwości, kształt i znaczenie. Tym samym kultura nowych mediów przenika i przekształca kulturę średniowiecza, odczytując ją w perspektywie technologii cyfrowej, odsłaniając to, co dotychczas było zakryte. Drugie ujęcie wskazuje na przekład jako działanie polityczne, bowiem - jako dokonywane w języku - zawsze jest podatne na wszelkiego rodzaju ideologizacje. Tak rozumiany przekład „otwiera się na wymiar etyczny i obejmuje

\footnotetext{
7 Autorem określenia przekładu jako przepisywania jest André Lefevere, zaś „pisanie od nowa” pojawia się w badaniach feministycznych nad translacją (Lefevere, 1985: 88-105; Mezei, 1985: 21-31).

8 Takie ujęcie proponuje Else Veira w ramach swojej pracy doktorskiej (Bassnett, 2010: 500-502).
} 
między innymi kwestię większego szacunku dla różnic językowych i kulturowych” (Ungar, 2010: 537). Trzeba by zatem na mediewalistyczną perspektywę relacji średniowiecze-nowe media spojrzeć z punktu widzenia języka. Język nowych mediów bynajmniej nie ma zadania niwelować różnicy wynikającej z nieprzystosowania języka źródłowego - kultury średniowiecznej i języka docelowego - współczesnej kultury: zmedializowanej i skomputeryzowanej, wręcz przeciwnie, ma ją wyraźnie eksponować. Trzeba bowiem stwierdzić za badaniami postkolonialnymi, że „język obcy nie nakłada się na język ojczysty niczym zwykły palimpsest, lecz go przemienia" , dokonuje aktu zróżnicowania, oddzielenia, ale i wyraźnego określenia jego tożsamości. Wszak przenoszenie języka, form, znaczenia nie odbywa się w próżni, zawsze istnieje już pewna matryca kulturowa, w którą zostaje wpisany tekst źródłowy. Jest to zatem język rozumiany jako doświadczenie kulturowe, z czym związany jest system poznawczy (rama kulturowa), który oddziałuje na tekst przekładany, wyznacza granice przekładu - sposobów przedstawiania dawności. Translacja byłaby zatem, jak pokazuje Hans Georg Gadamer, aktem hermeneutycznym, polegającym na transpozycji w inne medium, czyli na przeniesieniu „w nową rzeczywistość czytającego rozumienia, czy też w nowe dokonanie się rozumienia w jakimś obcym nam języku" (Gadamer: 163). Ten proces właśnie egzemplifikuje średniowieczność nowych mediów, które zilustruje fenomen kulturowy katedry.

Katedra gotycka jako tekst kultury jest zjawiskiem bardzo wieloznacznym, ze względu na swoją konstrukcję także polisemiotycznym, nacechowanym różnorodnymi odczytaniami historycznymi, także współczesnymi, żeby przywołać tylko ostatnie, wpisujące kulturowy fenomen w refleksję nad „świątyniami konsumpcji” (Regiewicz, 2003: 71-84). W tym tekście kultury przenikają się porządki: architektoniczny i teologiczny, społeczny i duchowy, artystyczny i komunikacyjny, w związku z tym jakiekolwiek próby uporządkowania dyskursu do jednej tylko optyki wydają się niemożliwe. Przedstawiona poniżej egzemplifikacja zatem nie ma na celu dokonywania kompletnego opisu, ale jest raczej szkicem, delikatnym kreskowaniem podskórnych powiązań media aetas i nowych mediów.

Jay David Bolter, przywołując na początku swoich rozważań o remediacji pisma fragment z Katedry Najświętszej Marii Panny Victora Hugo, zwraca uwagę, że wraz z wynalezieniem druku nastąpiła radykalna zmiana paradygmatu kulturowego -

9 Koncepcja ta jest bliska badaniom nad dwujęzycznością Abdelkebira Khatibiego (Ungar, 2010: 544). 
mowa kamienia została zastąpiona typografią. Hugo zamyka swoje rozważania niezwykle nośnym wyrażeniem: „księga zabije gmach” ${ }^{10}$.

Średniowieczna katedra wypełniona posągami i witrażami była nie tylko symbolem autorytetu chrześcijaństwa, ale i skarbnicą średniowiecznej moralności oraz wiedzy o świecie i ludzkiej kondycji. Katedra była biblioteką, której księgi odczytywali wierzący, krocząc nawami i podnosząc wzrok ku biblijnym scenom, wizerunkom świętych, alegoriom cnót i występków czy wizjom nieba i piekła.

(Bolter, 2014: 12)

Zacytowana wypowiedź Boltera na temat średniowiecznej budowli zwraca uwagę na kilka porządków znaczeniowych, wśród których warto wymienić: architektoniczność, polisemiotyczność oraz konstrukcję światopoglądową.

Średniowieczna katedra jawi się przede wszystkim jak „księga wykuta z kamienia”. Przemierzając przestrzeń świątyni, zwiedzający czyta zanurzone w tę przestrzeń, włączone w przekaz całości komunikaty, nie ulega bowiem wątpliwości, że katedra jest nośnikiem wiedzy i - jak nazywa ją Hugo - „wehikułem myśli ludzkiej”. Cała struktura świątyni: układ naw, usytuowanie ołtarza w przecięciu się ramion nawy głównej i bocznych, konstrukcja ostrołuków wnoszących się ku splotom na suficie i wiele innych elementów daje zwiedzającemu poczucie zetknięcia się z olbrzymią wiedzą: matematyczną, architektoniczną, ale i symboliczną, czy nawet katechetyczną. Wpisane w polichromię obrazy, napisy, posągi były dla czytającego katedrę punktami identyfikującymi: działały niczym sztuczna pamięć pomagająca w przyswajaniu i zapamiętywaniu scholastycznie ustrukturyzowanej wiedzy. Nie chodziło tu jednak o upostaciowienie i instrumentalne wykorzystanie architektury do przedstawienia teologicznej, scholastycznej summy, ale raczej o uruchomienie pamięci, na wzór ćwiczeń mnemotechnicznych, poprzez ruch ciała przemierzającego przestrzeń.

Kodyfikacja zapisu wiedzy w tych architektonicznych warunkach, regulowanie sposobu jej odczytywania, raczej nigdy nie będą stuprocentowe, co sprzyja lekturze niepełnej, wariantywnej, za każdym razem nieco innej. Pomogło to budowlom sakralnym pełnić swą najważniejszą rolę - jako interfejsu uniwersalnego i duchowego, który działa na rzecz nie tylko wiedzy czy pamięci, ale całej sfery sacrum.

\footnotetext{
10 „Kiedy porównamy myśl, która, chcąc wyrazić się w budowli, musi poruszyć cztery czy pięć innych sztuk i tony złota, i całą górę kamieni, i cały las belek, i cały lud robotników, kiedy ją porównamy z myślą, która staje się książką i której wystarczy trochę papieru, odrobina atramentu i pióro, czyż możemy się dziwić, że rozum ludzki porzucił architekturę dla druku? Przetnijcie znienacka pierwotne łożysko rzeki kanałem wykopanym poniżej jej poziomu, a rzeka porzuci swe dawne łożysko" (Hugo, 1976: 108).
} 
Świątynia, czy będzie nią Mahabodhi [w oryg. Mahbodi] czy Notre Dame, pełni rolę wykładni-interfejsu, stworzonego stosownie do rozwoju wiedzy i duchowości w epoce, w której powstała. W tym znaczeniu interfejs byłby oferowanym przez kulturę i technikę miejscem stykowym człowieka (jego ciała eksplorującego przestrzeń w rytualnym zdarzeniu) i absolutu: sumy wiedzy i duchowości, ku której podąża czytelnik/użytkownik w akcie lektury/eksploracji.

(Pisarski, 2014: 38)

Czytanie przestrzenne, utracone wraz z nastaniem druku, który sprowadził lekturę do aktu indywidualnego i statycznego, dystansując czytelnika od przedmiotu wiedzy, wraca poniekąd wraz z kulturą cyfrową. Dzieje się to poprzez zjawiska hipertekstowości i doświadczenie wirtualności. Pierwsze ze zjawisk - hipertekst jest nowym sposobem gromadzenia i prezentacji informacji, umożliwiającym strukturalizowanie i wyszukanie potrzebnych danych, bez konieczności czytania całych tekstów (Tomek, Maurer, 1992: 111-122). Przypomina swoją strukturą kłącze czy sieć, w których kolejne odgałęzienia krzyżują się, splatają, łączą w ten sposób, że powstaje konstrukcja niedająca się zmieścić na powierzchni. Przestrzenność hipertekstu wynika z jego węzłowej budowy, która pozwala czytelnikowi dowolnie sterować aktem lektury, podążając śladami różnych narracji: głównej i pobocznych zarazem, tekstowej i audiowizualnej. Powstaje w ten sposób trójwymiarowy układ przestrzennej sieci wiadomości. Użytkownik nowych mediów ma możność poruszania się w obszarze wiadomości zarówno wszerz, jak i w głąb, urządzenia telematyczne (komputer, iPod, tablet i inne) stwarzają możliwość dojścia do mikroskopijnego szczegółu wiedzy oraz szybkiego powrotu do punktu wyjścia, a tym samym pozwalają organizować lekturę w sposób indywidualny, dopasowany do osobistych oczekiwań. W efekcie hipertekst zwrócony jest ku odbiorcy, czyniąc go współtwórcą konstytuowanych podczas przechodzenia z leksji do leksji znaczeń, co wpływa niewątpliwie, jak pokazują badania, na proces edukacyjny: zdobywanie wiedzy, utrwalanie znaczen ${ }^{11}$. Byłby zatem hipertekst rozwiązaniem nie tylko przywracającym przestrzenny sposób czytania, ale także formą zdobywania wiedzy opartą na średniowiecznych tradycjach mnemotechnicznych.

Ponadto, żaden hipertekst nie jest jednorodny pod względem formy przekazu, bowiem łączy różnego typu teksty: od form pisanych, przez ikonograficzne, po audialne, audiowizualne, animacje cyfrowe i wirtualne, podobnie jak tekst katedry, w który wpisane są elementy sztuki rzeźbiarskiej, ikonograficznej, formy piśmien-

11 Stephen W. Draper pisze o hipertekście jako o „rękawicy dla umysłu”, która pozwala uczącemu się lepiej „złapać wiedzę” w trakcie uczenia się (Draper, 1992: 169-181). 
nicze i inne. Palimpsestowa budowa przekazu nowych mediów może zatem zostać odczytana w kontekście tradycji palimpsestu średniowiecznego. Trzeba by w tym miejscu szczególnie wyróżnić polisemiotyczny charakter przekazu komputerowego (Szczęsna, 2009: 272-283), który może być zestawiany z różnosemiotycznym tekstem katedry gotyckiej, na który składają się porządek teologiczny, architektoniczny, artystyczny, społeczny i inne.

Drugie z wymienionych zjawisk - wirtualność, na potrzeby niniejszego zderzenia media aetas $\mathrm{z}$ nowymi mediami, trzeba by zdefiniować przez pryzmat immersji. W doświadczeniu wirtualnym nie tyle chodzi o każdorazową obecność w sieci czy rzeczywistości cyfrowej, ale o „zanurzenie się” w niej, to znaczy silne powiązanie emocjonalno-psychiczne z rzeczywistością cyfrową, istniejącą analogicznie i równolegle do świata rzeczywistego, a wykreowaną za pomocą urządzeń elektronicznych. Wirtualność sprzężona jest z koncepcją symulakryczności, która ustawia użytkownika w specyficznej relacji do elektronicznej symulacji - potencjalnego uczestnictwa w równoległym i niezależnym świecie. Zakorzeniony w świecie realnym użytkownik nowych mediów jest, dzięki odpowiednim narzędziom technologicznym, zanurzony w świat wirtualny, co powoduje, że może on między tymi światami swobodnie się poruszać. To znaczy, że wirtualność i rzeczywistość jako światy odrębne zazębiają się, nakładają na siebie lub inaczej - współistnieją ze sobą. Poruszanie się po świecie wirtualnym jest zarazem nawigowaniem po rzeczywistości cyfrowej, jak i odczytywaniem jej znaczeń. Dzięki odpowiednim artefaktom rozmieszczonym w świecie wirtualnym, których znaczenie trzeba zdenotować, użytkownik może poruszać się po tej cyfrowej rzeczywistości, przechodzić z narracji do narracji, planu do planu. Tym samym czytanie staje się nawigowaniem, działaniem w przestrzeni.

Analizując koncepcję przestrzennego zarządzania danymi, w której przykładem mogą być metaforyczne pulpity mediów komputerowych oraz symulowane środowiska robocze, można zauważyć paralelę między tymi współczesnymi praktykami a strategiami zapamiętywania w katedrze. Podobnie internetowa baza danych może budzić skojarzenia ze średniowiecznymi gatunkami encyklopedycznymi, obficie wykorzystującymi struktury znanych budowli jako sposób kategoryzowania i gromadzenia wiedzy dającej się zakodować, zapamiętać, a potem odszukać. Wybitnym tego przykładem jest Arka Noego, której program ikonograficzny i domyślną architekturę wiedzy zbudował Hugo od św. Wiktora w jednym z nauczycielskich traktatów. W ten sposób można by tłumaczyć także tendencję średniowiecznych myślicieli do katalogowania, klasyfikowania i układania wiedzy na wzór architektoniczny (Lewis, 1986; Eco, 2009). 
Wspomniane wcześniej funkcje dydaktyczna i katechetyczna katedry korespondują z coraz powszechniejszym wykorzystywaniem interaktywnej techniki komputerowej i pakietów edukacyjnych programów komputerowych, które mogą świadczyć o powrocie do oralno-wizualnej kultury średniowiecznej. Zjawisko to, typowe dla nowych mediów, umożliwia odniesienie do średniowiecznego edutainment wyrażonego w niezliczonych formach graficznego przedstawiania treści oraz wspomagania pamięci i wyobraźni w mapach, diagramach, przedmiotach, postaciach, z których nie wszystkie były zrealizowane graficznie, a mogły być tworzone przez uczniów lub kopistów na podstawie słownego opisu. Należą tu wszelkie odmiany ilustracji do cykli narracyjnych wpisanych w polichromię, a może nawet popularna forma wykładu typologii biblijnej znana jako Biblia pauperum (Knapiński, 2004: 133-164). Ta permanentna wizualizacja doświadczenia nadawczo-odbiorczego, ujawniająca się chociażby poprzez ikony i przestrzenie ekranu komputerowego, przypomina mnemotechniczne tradycje średniowieczne.

Przywołany w nieco innym kontekście monitor czy ekran urządzenia telematycznego, ze względu na emitowanie światła, pozwala odnieść się do funkcji, jakie to pełniło w katedrze. Warto przywołać w tym miejscu średniowieczną teologię światła Sugera, według którego

światło boże w sposób szczególny nasycało pewne przedmioty wybrane. Podobnie jak rozwiązania architektoniczne przedmioty te zachęcały duszę, by do tego, co stworzone, wznosiła się ku temu, co ponadczasowe, do tego, co zamknięte w materii, zwracała się ku niewysłowionemu

(Duby, 1997: 97).

Światło - bardzo znacząca metafora w teologii chrześcijańskiej - staje się dla architektury gotyckiej zapleczem światopoglądowym. Jest podstawą myślenia o kubaturze świątyni, konstytuuje porządki symboliczne, wymusza w pewien sposób konstrukcję przestrzenną. Wrażenie, jakie wywołuje w odbiorcy, jest niebagatelne, począwszy od doznań czysto estetycznych (piękno, czystość, wzniosłość) przez uniesienie modlitewne (stany mistyczne), aż do funkcji epistemologicznej, która wspomaga rozpoznanie i odzyskiwanie wiedzy ukrytej w świątyni. Podobnie w świecie nowych mediów, światło, stając się podstawowym tworzywem obrazu, zostaje podniesione do rangi dzieła ${ }^{12}$. Nie jest ono już efektem zewnętrznego oświecenia powierzchni, jak w przypadku projektora i taśmy filmowej, ale samym świeceniem

$12 \mathrm{Na}$ rolę światła w budowaniu nowych form artystycznych zwracali uwagę twórcy Bauhausu w latach 20. XX wieku. 
ekranu, stając się przekazem samym w sobie. Obraz elektroniczny imituje światło z „wnętrza”, ale nie skupia go, a rozprasza, rozświetla przestrzeń, w której się znajduje. Ta zaś jest zawsze „tylko obrazem światła rozłożonego na jego emisyjne parametry, simulacrum obrazu przekaźnika, obrazu, którego w istocie brak. (...) to pozbawiona faktury matryca wypełniona energią świetlną" (Gwóźdź, 1994: 148). Dlatego ekran staje się często źródłem światła w przestrzeni, pełni funkcję nośnika światła (lucy pherus), które rozświetla otaczającą go przestrzeń.

Ta ostatnia uwaga pozwala spojrzeć na analizowaną relację przez pryzmat podobieństwa funkcji teologii i technologii, które stają się dla tak różnych sposobów wyrażania zapleczem światopoglądowym. Jeśli określenie teologii jako idei fundamentalnej dla rozwoju estetyki gotyckiej nie budzi zastrzeżeń, to zazwyczaj spoglądanie na technologię w podobnym kontekście wywołuje lawinę protestów. A jednak sytuacja filozoficzno-duchowa współczesnego człowieka - homo irretitus - poszukującego w cyberprzestrzeni namiastki świata metafizycznego, pozwala na wyprowadzenie kilku wniosków (Regiewicz, 2013: 199-219). Technologia - co czasem trudno zauważyć - nigdy nie jest apolityczna, zawsze wyraża społeczne pragnienia i lęki, o czym pisał cytowany wcześniej Eco, ukazując jej rolę w oswajaniu przez człowieka średniowiecza strachu. W ten sposób trzeba by spojrzeć na jej rolę we współczesnej kulturze nowych mediów. Technologia jawi się bowiem jako zespół mechanizmów „uprawiających ducha”, tym samym udostępnia ludzkości realia historii i teraźniejszości oraz wszelkie możliwe formy twórczości. Podobnie jak Bóg, technologia staje się działaniem wszechogarniającym, natychmiastowym, niezwykle żywotnym (to znaczy, mającym moc kreacyjną, powołującą do istnienia, nawet jeśli jest to tylko życie cyfrowe), czego wyrazem są zarówno elektroniczna planetarna metainteligencja, tworząca wszechogarniającą świadomość globalną wyrażoną poprzez internetowy metaumysł, jak i właściwości cyfrowych maszyn w postaci hiperprędkości czy nieskończoności (także niezniszczalności, nieusuwalności kopii - coś, co zostaje wrzucone do sieci, już nie znika). Podobnie jak niegdyś teologia, dziś technologia konstytuuje tożsamość człowieka, jego podejście do ciała, potrzeb duchowych, odnoszenie się do sfer zmysłowych i pozazmysłowych. W tej perspektywie można by jeszcze raz odwołać się do doświadczenia wirtualności. Sytuacja człowieka średniowiecza wydaje się przypominać współczesnego użytkownika nowych mediów, który zanurza się w świat wirtualny - relację ciała i podmiotowości wirtualnej można by opisać średniowiecznym wierszem „dusza z ciała wyleciała”. Co ciekawe, digitalna ucieczka od fizyczności elektronicznych światów jest zbieżna z religijnymi doświadczeniami ducha. Podobnie kiedy spojrzeć na średniowieczne wyobrażenia zaświatów, formy myślenia symbolicznego i mistyczne doświadczenia 
świętych, można tu wskazać analogie pomiędzy tak, wydawałoby się, odległymi praktykami kulturowymi, ukazując wspólne źródło pragnień i potrzeb człowieka średniowiecznego i postindustrialnego.

Zarysowane powyżej zagadnienia, oparte na figurze katedry, ukazujące podobieństwo między nowymi mediami a praktykami kulturowymi średniowiecza, pozwalają diagnozować współczesną sytuację kultury, a zarazem przyglądać się sposobom funkcjonowania człowieka w systemie komunikacyjnym. Badając doświadczenia kulturowe średniowiecza w perspektywie praktyk nowych mediów, można postawić tezę o przekładalności mechanizmów średniowiecznego uniwersalizmu na stechnicyzowane procesy globalizacji, a tym samym lepiej rozumieć sytuację współczesnego człowieka w nowomedialnej rzeczywistości, jak również samą kulturę, w której się porusza, i tożsamość, którą przyjmuje. A przekładalność ta możliwa jest dzięki komparatystyce.

\section{Bibliografia}

Bassnett, Susan. „Od komparatystyki literackiej do translatologii”. Przeł. Agnieszka Pokojska. Niewspótmierność. Perspektywy nowoczesnej komparatystyki. Antologia. Red. Tomasz Bilczewski. Kraków: Wydawnictwo Uniwersytetu Jagiellońskiego, 2010. 481-509.

Bernheimer, Charles. „Wstęp. Lęki przed porównaniem”. Przeł. Piotr Sobolczyk. Niewspótmierność. Perspektywy nowoczesnej komparatystyki. Antologia. Red. Tomasz Bilczewski. Kraków: Wydawnictwo Uniwersytetu Jagiellońskiego, 2010. 115-136.

Bierdiajew, Nikołaj. Nowe Średniowiecze. Los cztowieka we wspótczesnym świecie. Przeł. Henryk Paprocki. Warszawa: Fundacja Aletheia, 2003.

Bolter, Jay David. Przestrzeń pisma. Komputery, hipertekst i remediacja druku. Przeł. Aleksandra Małecka, Michał Tabaczyński. Kraków: Korporacja Ha!art, 2014.

Bukowski, Piotr, Heydel, Magda. „Wprowadzenie: przekład - język - literatura”. Wspótczesne teorie przektadu. Antologia. Red. Piotr Bukowski, Magda Heydel. Kraków: Znak, 2009. 5-37.

Dawnośc kulturowa w literaturach stowiańskich II pot. XX wieku. Red. M. Kaczmarek. Opole: Wydawnictwo Wyższej Szkoły Pedagogicznej, 1993.

Derrida, Jacques. Wieża Babel. Przeł. Adam Dziadek. Wspótczesne teorie przektadu. Antologia. Red. Piotr Bukowski, Magda Heydel. Kraków: Znak, 2009. 373-383.

Draper, Stephen W. „Gloves for the mind”. Cognitive tools for learning. Eds. Piet A.M. Kommers, David H. Jonassen, J. Terry Mayes. Berlin-Heidelberg: SpringerVerlag 1992. 169-181. 
Duby, George. Czasy katedr. Przeł. Krystyna Dolatowska. Warszawa: Cyklady, 1997.

Eco, Umberto. Nowe Średniowiecze. Przeł. Piotr Salwa. Tegoż. Semiologia życia codziennego. Warszawa: Czytelnik,1998. 74-101.

----. Szaleństwo katalogowania. Przeł. Tomasz Kwiecień. Poznań: Dom Wydawniczy Rebis, 2009.

Ferris, David. „Dyscyplina poza dyscypliną”. Przeł. Jakub Momro, Tomasz Bilczewski. Niewspótmierność. Perspektywy nowoczesnej komparatystyki. Antologia. Red. Tomasz Bilczewski. Kraków: Wydawnictwo Uniwersytetu Jagiellońskiego, 2010. 243-273.

Gadamer, Hans Georg. Jak dalece język dyktuje myślenie? Przeł. Andrzej Przyłębski. Andrzej Przyłębski, Gadamer. Teksty w „Wyborze pism”. Warszawa: Wiedza Powszechna, 2006. 156-164.

Gwóźdź, Andrzej. „Elektroniczne gry świetle”. Prędkość i przyjemność. Kino i telewizja $w$ dobie symulacji elektronicznej. Red. Andrzej Gwóźdź. Kielce: Szumacher, 1994. 135-153.

Hugo, Victor. Katedra Najświętszej Marii Panny. Przeł. Hanna Szumańska-Grossowa. Warszawa: Państwowy Instytut Wydawniczy, 1976.

Husserl, Edmund. Idea fenomenologii. Przeł. Janusz Sidorek. Warszawa: Wydawnictwo Naukowe PWN, 2008.

Kaczmarek, Marian. „Dawność kulturowa w literaturze XX wieku (średniowiecze renesans - barok - oświecenie)”. Stownik literatury polskiej XX wieku. Red. Alina Brodzka i in. Wrocław: Zakład Narodowy im. Ossolińskich, 1992. 166-171.

Kadłubek, Zbigniew. Święta Medea. W stronę komparatystyki pozastownej. Katowice: Wydawnictwo Uniwersytetu Śląskiego, 2010.

Kalaga, Wojciech. „Granice tekstu - mgławice tekstu”. Teksty Drugie 4 (1998): 5-32.

Knapiński, Ryszard. „Biblia Pauperum. Rzecz o dialogu słowa i obrazu”. Nauka 4 (2004): 133-164.

Lewicki, Grzegorz. „Sieciowa teoria Nowego Średniowiecza”. Pressje 20 (2010): 77-96.

Lefevere, André, „What Is Written Must Be Rewritten, Julius Caesar: Shakespeare, Voltaire, Wieland, Buckingham". Second Hand: Papers on the Theory and Historical Study of Literary Translations. Ed. Theo Hermans. Antwerp: ALW, 1985. 88-105.

Lewis, Clive Staples. Odrzucony obraz. Wprowadzenie do literatury średniowiecznej i renesansowej. Przeł. Witold Ostrowski. Kraków: Znak, 1986.

Medievalism in the Modern World. Essays in Honour of Leslie Workman. Eds. Richard Utz, Tom Shippey. Turnhout: Brepols Publisher, 1998.

Mezei, Kathy. „The Raeder and the Decline”. Tessera: L'Écriture comme Lecture 9 (1985): 21-31.

Michalski, Maciej. „Wokół definicji mediewalizmu”. Śląski Kwartalnik Historyczny. Sobótka 1 (2011): 83-91. 
Pisarski, Mariusz. „Sztuka dawna w świetle sztuki cyfrowej: w stronę teorii kulturowych interfejsów (zarys)". Maszyny kruszenia stowa. Biuletyn konferencyjny. Red. Adam Regiewicz. Częstochowa, 2014. 35-44 (na prawach maszynopisu).

Regiewicz, Adam. „Na urodzinach u Geanta, czyli antropologiczne opisanie nowego miasta". Studia Laurentiana 1 (2003): 71-84.

----. „Teologia nowych mediów”. Więzi Wspólnoty. Literatura-religia-komparatystyka. Red. Piotr Bogalecki, Alina Mitek-Dziemba, Tadeusz Sławek. Katowice: Wydawnictwo Uniwersytetu Śląskiego, 2013. 199-219.

----. Mediewalizm wobec zjawisk audiowizualnych i nowych mediów. Warszawa: DiG, 2014.

Regiewicz, Adam, Utracka, Dorota. „Perspektywy komparatystyki kulturowej. Na przykładzie programu Pracowni Komparatystyki Kulturowej Akademii im. Jana Długosza w Częstochowie”. LUD 95 (2011): 261-272;

Schmidt, Siegfried J. „Literaturoznawstwo jako projekt interdyscyplinarny”. Przeł. B. Balicki. Teksty Drugie 4 (2010): 151-167.

Simmons, John. „Christopher Middleton on Elizabethan Medievalism”. Medievalism in the Modern World. Essays in Honour of Leslie Workman. Eds. Richard Utz, Tom Shippey. Turnhout: Brepols Publisher, 1998. 43-60.

Steiner, George, „Czym jest literatura porównawcza?”. Przeł. Irena Hansz. Przegląd Polityczny 93 (2009a): I-VIII.

----. „Ruch hermeneutyczny”. Przeł. Olga i Wojciech Kubińscy. Wspótczesne teorie przektadu. Antologia. Red. Piotr Bukowski, Magda Heydel. Kraków: Znak, 2009b. 327-334.

Stoff, Andrzej. Studia z teorii literatury i poetyki historycznej. Lublin: Towarzystwo Naukowe Katolickiego Uniwersytetu Lubelskiego, 1997.

Szahaj, Andrzej. „Granice anarchizmu interpretacyjnego”. Teksty Drugie 6 (1997): 6-33.

Szczęsna, Ewa. „Znak w cyfrowym świecie, Semiotyczne aspekty komunikacji komputerowej”. Komunikowanie się w mediach elektronicznych. Język, edukacja, semiotyka. Red. Mirosław Filiciak, Grzegorz Ptaszek. Warszawa: Wydawnictwa Akademickie i Profesjonalne, 2009. 272-283.

Tomek Ivan, Maurer Hermann, „Helping the user to select a link”. Hypermedia 4.2 (1992): 111-122.

Tymoczko, Maria. „Literatura postkolonialna i przekład literacki”. Wspótczesne teorie przektadu. Antologia. Red. Piotr Bukowski, Magda Heydel. Kraków: Znak, 2009. 429-447.

Ungar, Steven., „«Pisanie językami». Rozważania o dziele tłumaczonym”. Przeł. Agnieszka Pokojska. Niewspótmierność. Perspektywy nowoczesnej komparatystyki. Antologia. Red. Tomasz Bilczewski. Kraków: Wydawnictwo Uniwersytetu Jagiellońskiego, 2010. 531-546.

White, Hayden. Metahistory: The Historical Imagination in Nineteenth-Century Europe. Baltimore-London: The Johns Hopkins University Press, 1973. 


\title{
Comparative Studies - A Method for Reading Antiquity. The Case of Medievalism
}

\begin{abstract}
Summary
The past is not a constant, but an ever-changing conglomerate of meanings. Making an attempt at applying comparative tools, such as theories of translation, discourse, intertextuality, etc. to the study of the antiquity, this paper illustrates the wide spectrum of interrelations between the present day (considered in particular within the perspective of new media and technologies) and the Middle Ages, or as one should term it, its cultural readings, referred to as medievalism. To that end, it undertakes the analysis of phenomena from within the scope of communication technology from a transcultural and ahistorical perspective: media aetas - new media, permitting their description as the effect of the coexistence of cultural practices which had already occurred within the medieval tradition, and thus formulating conclusions regarding the formation of relationships between contemporary man and the world through the media.
\end{abstract}

Keywords: comparative literature, medievalism, antiquity, new media

Słowa kluczowe: komparatystyka literacka, średniowieczność, dawność, nowe media 